\title{
$\frac{100}{\mathrm{WiT}}$ RPESS
}

\section{WOKÓŁ PROBLEMATYKI GATEKEEPERÓW W PRAWNICZEJ KOMUNIKACJI NAUKOWEJ}

„Gatekeeper - w klasycznym ujęciu - oznacza selekcjonera, odźwiernego, bramkarza, który jest osobą decydujaca o tym, które informacje i w jakiej formie (filtrowanie) będą rozpowszechniane. Inaczej ujmujacc, rozstrzyga on, które informacje wejdą do obiegu, a które nie. Ważne jest zwrócenia uwagi na fakt, iż gatekeeperzy przez swoje decyzje moga realnie kontrolować poziom wiedzy w społeczeństwie. Należy dodać, iż rolę selekcjonera mogą odgrywać nie tylko jednostki, ale instytucje, które określaja, które wydarzenia maja wartość, a które nie"1.

Przedmiotem artykułu są wybrane problemy podmiotów mających istotny wpływ na wybór prawniczych wyników badań naukowych, które są ujawniane, publikowane, dostarczane adresatom, a niekiedy traktowane jako poufne i niejawne ${ }^{2}$. To zadania, w których realizacji biorą udział różne podmioty, można uznać, że są to selekcjonerzy (gatekeeperzy) uczestniczący w prawniczej komunikacji naukowej.

Prawnicza komunikacja naukowa jest rozumiana w tym tekście jako komunikacja między naukowcami oraz jako komunikacja transformowana z nauki do praktyki prawniczej. To także przekazywanie przez naukowców zamawianych wyników badań innym interesariuszom zewnętrznym (do biznesu, przemysłu, polityki) oraz komunikacja naukowców ze społeczeństwem, bezpośrednia albo poprzez dziennikarzy naukowych. Chodzi o komunikację naukowa, która jest adekwatna, czyli taka, która dociera do adresatów z informacjami, których oni potrzebują (standard istotności treści przekazu), w miejscach, do których mają dostęp, biorąc pod uwage ich typowe wzorce wyszukiwania

\footnotetext{
* Jolanta Jabłońska-Bonca, Akademia Leona Koźmińskiego w Warszawie, jablonska@kozminski.edu.pl, https://orcid.org/0000-0002-0894-9558,

Redaktor naczelny czasopisma „Krytyka Prawa”.

1 Szpunar (2013): 57.

${ }^{2} \mathrm{Na}$ temat zaufania do różnych typów aktorów w komunikacji naukowej oraz do różnych kanałów używanych do przekazywania wiedzy naukowej zob. np. Weingart, Guenther (2016).
} 
(standard bliskości) dla dostępności informacji, oraz w formie, z której moga korzystać ${ }^{3}$.

Począwszy od wieku XVII do końca XX komunikację naukową utożsamiano głównie z publikowaniem artykułów i recenzji w tradycyjnych, papierowych czasopismach naukowych, wystapieniami na konferencjach oraz monografiami i podręcznikami ${ }^{4}$. W XXI w. nośnikami komunikacyjnymi - poza tradycyjnymi mediami masowymi popularyzującymi i udostępniajaccymi wiedzę prawniczą - stały się także e-czasopisma, repozytoria online, e-blogi naukowe, naukowe serwisy online, platformy udostępniające wideo online ${ }^{5}$. Pojawiły się też nowe zjawiska samopublikowania i autoarchiwizacji tekstów online przez naukowców.

Te nowe kanały udostępniają naukową i popularnonaukową wiedzę prawniczą często bezpłatnie, są zazwyczaj otwarte (open access), bez względu na miejsce i czas umożliwiają bezpośrednie interaktywne relacje naukowca i odbiorców komunikatów, w tym między innymi natychmiastowe nieautoryzowane komentarze czytelników. Tylko niektóre utwory oryginalne udostępniane przez te kanały mogą być jednak uznawane za spełniające wymagania artykułów naukowych ${ }^{6}$.

Podstawowe pytania stawiane w tym tekście są następujące: Czy i jak zmieniają się obecnie drogi prawniczej komunikacji naukowej, kto ma ważny albo decydujący wpływ na filtrowanie wyników naukowych badań prawniczych, które trafiają do publicznego dyskursu prawniczego, oraz kto i dlaczego może zamykać niektóre „bramki” (gate), ograniczając albo wykluczając dostęp naukowców, praktyków albo społeczeństwa do określonych treści? ${ }^{7}$ Czy i jaki wpływ na zjawiska istnienia „bramek” ma kultura cyfrowa? Czy fakt dynamicznego rozwoju otwartej komunikacji naukowej (open access) ma wpływ na to, kto jest gatekeeprem? Czy wraz z upowszechnianiem Internetu jest mniej punktów selekcji, a może sa, ale inne? ${ }^{8}$

3 To ważne, aby na przykład komunikować wyniki dogmatycznych nauk prawnych w języku, w którym mówią prawnicy na co dzień.

${ }^{4}$ Utwór opublikowany to taki, „który za zezwoleniem twórcy został zwielokrotniony i którego egzemplarze zostały udostępnione publicznie" (art. 6 ust. 1 pkt 1 ustawy prawo autorskie Dz. U. 1994, Nr 24, poz. 83). Artykuł naukowy natomiast jest to „recenzowany artykuł opublikowany w czasopiśmie naukowym albo w recenzowanych materiałach z międzynarodowej konferencji naukowej: 1) przedstawiający określone zagadnienie naukowe w sposób oryginalny i twórczy, problemowy albo przekrojowy; 2) opatrzony przypisami, bibliografią lub innym właściwym dla danej dyscypliny naukowej aparatem naukowym. 2. Artykułem naukowym jest również artykuł recenzyjny opublikowany w czasopiśmie naukowym zamieszczonym w wykazie czasopism. 3. Artykułem naukowym nie jest: edytorial, abstrakt, rozszerzony abstrakt, list, errata i nota redakcyjna”. (Por. rozporządzenie z 22 lutego 2019 r. w sprawie ewaluacji jakości działalności naukowej, Dz. U. 2019, poz. 394).

${ }_{5}^{5}$ Pomijam tu problemy wydawnictw książkowych, tradycyjnych i e-booków.

${ }^{6}$ Wymagania są określane przez prawo. W Polsce zob. przy. 4. Uznanie artykułu za naukowy przez uczelnię albo instytut naukowy nadal jest uzależnione na ogół od listy czasopism ogłoszonej jako decyzja organu państwa lub od międzynarodowej, prywatnej, uznanej listy czasopism.

7 „Bramka” - tu: punkt selekcjonowania tekstów w kanałach komunikacji naukowej.

8 Szeroko na temat zmian w gatekeepingu por. Shoemaker, Vos (2009). 
Fakt istnienia „bramek”, czyli punktów, w których informacje (tu: naukowe i popularnonaukowe teksty prawnicze) sa filtrowane, „przepuszczane” do adresatów albo „blokowane”, nie podlega dyskusji. Jest dobrze udokumentowany w naukach społecznych, szczególnie w naukach o komunikowaniu i w medioznawstawie ${ }^{9}$. Decyzje o filtrowaniu podejmują tzw. gatekeeperzy. Kim są i jaki mają wpływ na przepustowość medialnych dróg prawniczej komunikacji naukowej? Czy i jaki mają wpływ na istotność, bliskość i formy przekazu?

Gatekeeperami sa wydawcy naukowych pism (uczelnie, instytuty naukowe, wyspecjalizowani wydawcy komercyjni), inne podmioty finansujace wydawane czasopisma, redaktorzy naczelni, recenzenci, dziennikarze naukowi, organy państwa (twórcy polityk naukowych), sponsorzy, fundatorzy, zleceniodawcy zamawiający badania dla biznesu, przemysłu i struktur państwa, międzynarodowe bazy danych naukowych, a także wyszukiwarki internetowe zaliczane do tzw. gatekeepingu technologicznego ${ }^{10}$. Podmioty te maja wpływ na ogłaszanie i udostępnianie oraz hierarchizowanie tekstów naukowych, a co za tym idzie - tez naukowych, które są przekazywane odbiorcom. Obraz komplikują różne formy samopublikacji w Internecie, jednak nie ma wątpliwości, że w dobie cyfrowej transformacji komunikacji naukowej teksty naukowe są nadal filtrowane, choć niektóre „bramki” są ustawione w innych miejscach.

Przeobrażają się także drogi popularyzacji prawniczych wyników naukowych, czyli komunikacja tych wyników do społeczeństwa. Przekaz naukowca docierał do odbiorców w czasach tradycyjnych mediów masowych bardzo często poprzez gatekeepera, jakim był profesjonalny dziennikarz naukowy, który miał wpływ na treści rzeczywiście docierające do odbiorcy. Dziennikarz naukowy to specjalista $\mathrm{w}$ udostępnianiu złożonych tematów czytelnikom, ale może też zmienić akcenty w przekazie pierwotnym, dokonywać selekcji przekazywanych treści ${ }^{11}$.

Naukowcy rozumieją obecnie na ogół, że powinni sami też popularyzować swoje wyniki. Prawnicze dziennikarstwo naukowe z powodu wielu nowych możliwości rozpowszechniania wiadomości w Internecie traci na znaczeniu.

Komunikację naukową podzielić można na „otwartą" i „zamkniętą"12. Kierunek open access $\mathrm{w}$ naukach finansowanych ze środków publicznych jest bardzo wyraźny, rozwija się szybko. Akcentowane jest w nim dobro publiczne. Podnosi się, że wyniki badań finansowane ze środków publicznych powinny być bezpośrednio i nieodpłatnie przekazywane społeczeństwu, wszechstronnie rozpowszechniane, należy się nimi dzielić ${ }^{13}$.

${ }_{9}$ Por. np. White (1950): 383-390, cyt. za: Szpunar (2013): 56-65; McCombs (2008).

${ }^{10} \mathrm{~W}$ państwach niedemokratycznych polityczni cenzorzy.

${ }^{11}$ Łojko (2013).

${ }^{12}$ Idea otwartej nauki i otwartego dostępu jest wspierana przez Unię Europejska. Od 2015 r. Polska ma oficjalna politykę open access.

${ }^{13}$ Por. Deklaracja berlińska w sprawie otwartego dostępu do wiedzy w naukach ścisłych i humanistyce. Dostępna na: <http://oa.mpg.de/lang/en-uk/berlin-prozess/berliner-erklarung/> [dostęp: 20.02.2021]. 
Czasopisma prawnicze open access sa powszechnie dostępne w Internecie ${ }^{14}$. W ramach otwartego dostępu są dwa główne kanały dostępu: „złota droga” i „zielona droga” ${ }^{15}$. „Złota droga” oznacza, że czasopismo gwarantuje otwarty dostęp do wszystkich artykułów na swojej internetowej stronie, „zielona droga" otwartego dostępu to deponowanie i archiwizowanie własnych utworów, a także preprintów i postprintów w repozytoriach ${ }^{16}$.

Czasopisma prawnicze pełnią wiele funkcji w komunikacji między naukowcami i specyficznych funkcji w naukach prawnych, mają istotny wpływ na kształt treści prawa, oddziałując na praktyki interpretacyjne i prawotwórcze. Doktryna prawnicza współkształtuje normy systemu prawa. Autorzy tekstów ustalają granice „pola władzy” nad znaczeniami, decydując o drogach wykładni przepisów prawa.

Aktualnym problemem w Polsce jest wyraźne rozwarstwienie czasopism, na te, które z powodu takich, a nie innych zasad ewaluacji i akredytacji walcza o „punkty”, i te, które - choć mają długą tradycję i są ważnymi elementami polskiej kultury prawnej i prawniczej - „poddały się”. Są wydawane między innymi przez podmioty związane z organami samorządów prawniczych, przez stowarzyszenia prawników. Są użyteczne w praktyce prawniczej.

Ponadto krajobraz form komunikacji i standard bliskości w ostatnich 30 latach uległ przekształceniu: obieg informacji naukowej globalizuje się, a wiele funkcji tradycyjnych czasopism przejęły internetowe kanały dystrybucji wiedzy ${ }^{17}$.

Są jednak dwie bardzo ważne dla kultury prawnej funkcje pełnione tradycyjnie przez czasopisma naukowe oraz niektóre czasopisma praktyków „wypchnięte" z listy ministerialnej, których nie udało się dotąd skutecznie przejąć nowym formom informacji w sieci, takim jak np. e-blogi, repozytoria online czy e-platformy społecznościowe.

Po pierwsze, czasopisma (i książki, wystapienia na konferencjach) w formie papierowej, hybrydowej i elektronicznej tradycyjnie sa uznawane za fundament procesu ugruntowywania wiedzy prawniczej jako rodzaju ważnej praktyki społecznej. Staje się to problemem, jeśli z tradycyjnym środowiskowym uznaniem wagi pism nie do pogodzenia sa koncepcje popierania określonej linii polityki naukowej państwa, a listy czasopism ustalane przez organy władzy albo prywatne firmy sa przez środowisko prawnicze kwestionowane. A po drugie, nadal to czasopisma (książki i wystapienia) sa podstawą jakościowej

14 Conte; Schmitz (2017); Gannon (2004).

${ }^{15}$ W literaturze odróżnia się także otwarty dostęp i wolny dostęp: „w pierwszym przypadku chodzi o udostępnienie publikacji przez Internet każdemu bez ograniczeń technicznych, jednak bez zezwolenia na korzystanie szersze, niż wynika to z przepisów prawa autorskiego o dozwolonym użytku. Natomiast w drugim przypadku publikacja jest udostępniona wraz z dodatkową zgodą uprawnionego na korzystanie z niej przez każdego w bardzo szerokim zakresie”, cyt. za: Siewicz (2012): 12. Na temat otwartego dostępu, otwartej nauki zob. pracę zbiorową Kulczycki (2017).

16 Są też w pełni otwarte czasopisma, otwarte czasopisma z embargiem czasowym oraz hybrydowe otwarte czasopisma. Szeroko na temat open access np. Kulczycki (2013). Por. też: Mrozowska (2017).

17 Elektroniczne czasopisma hybrydowe - dostępne za pośrednictwem kanałów elektronicznych, ale zachowujące dystrybucję opartą na papierze. 
weryfikacji udostępnianej wiedzy. Komunikacja naukowa poprzez czasopisma (książki, wystapienia) jest uznawana za ważną część procesu naukowego tak samo jak gromadzenie, analiza czy synteza danych.

Od ponad 200 lat uznane czasopisma prawnicze, wydawnictwa i konferencje określaja, kto należy do mainstreamu debat o prawie. Obecnie w Polsce oficjalne uznanie jest efektem politycznej decyzji władczej państwa, nie jest skutkiem oceny środowiskowej. Uznanie to poprzedza jednak selekcja tekstów w redakcjach.

Na czym polega gatekeeping w redakcjach czasopism? Redakcje dysponuja władzą nad prawniczymi nurtami badań, moga skutecznie promować albo eliminować możliwość podejmowania określonych tematów, zamykać dyskursy dla ochrony pewnych wartości politycznych i prawnych albo dla ochrony paradygmatów badań i strategii stosowania prawa.

Dostęp otwarty do czasopism konkuruje z dostępem zamkniętym, tradycyjnym (zwanym tu „pierwszym poziomem zamknięcia”), który oznacza na ogół opłaty za prenumeratę pisma albo za pojedyncze strony ${ }^{18}$. Czasopisma closed access sa dostępne w wersji papierowej albo sa widoczne online wyłącznie dla osób w instytucjach, które są subskrybentami, oraz na ogół jedynie z komputerów jednostek, które zakupiły te subskrypcje. Instytucje akademickie i badawcze opłacaja dostęp do konkretnych baz danych. Ceny subskrypcji sa jednak dla wielu potencjalnych zainteresowanych (także uczelni) zaporowe. Wysokie koszty subskrypcji powoduja, że wiele bibliotek na świecie je w ostatnich latach anuluje ${ }^{19}$. Autor artykułu nie ma na ogół na podstawie umowy z wydawca prawa rozpowszechniać nigdzie jego kopii i samodzielnie umieszczać go na swojej stronie w Internecie. Dostęp zamknięty całkowicie (tu: „drugi poziom zamknięcia”) oznacza, że wyniki badań naukowych sa poufne i jawne wyłącznie dla zamawiającego podmiotu.

Znaczenie dla rozwoju nauk prawnych każdej z tych dróg jest inne. W każdym przypadku włącza się gatekeeper, a jego pozycja wyraża jakiś poziom władzy nad prawniczą komunikacją naukową.

Walka o władzę nad nauka, w tym o dostęp oraz o opublikowanie, jest codziennością i jest to, niestety, często walka per fas et nefas. Większość prawników naukowców prowadzących współcześnie badania musi podejmować różne transakcyjne gry z interesariuszami systemu szkolnictwa wyższego i nauki albo z interesariuszami praktyki prawniczej, biznesu, przemysłu i władzy, ubiegając się o dobra, które są ważnymi albo nawet koniecznymi środkami do uzyskania satysfakcjonujących (np. satysfakcja z pracy dla dobra wspólnego albo z wynagrodzenia) efektów pracy badawczej ${ }^{20}$. Naukowiec musi stosować

18 Dwa poziomy zamknięcia wyodrębniam dla potrzeb tego tekstu.

${ }^{19} \mathrm{~W}$ tle jest poważny problem opłacalności ekonomicznej otwartego dostępu zarówno dla wydawców, jak i dla autorów. Na świecie rosną opłaty autorskie za publikacje w otwartym dostępie. Kształtują się one od 1,5 tys. dolarów do 6 tys. dolarów za artykuł. Zob. bliżej: Gannon (2004). Dane nie odnoszą się do Polski, gdzie publikowanie w uczelnianych pismach prawniczych otwartych jest co do zasady nieodpłatne. Sytuacja taka w dłuższej perspektywie wydaje się nie do utrzymania.

${ }^{20}$ Karcz (2016): 173-184. 
rozmaite strategie i taktyki w różnych fazach procesu badawczego; począwszy od etapu zdobywania środków na badania po fazę przenoszenia komunikowania wyników badań naukowych do świata nauki i praktyki.

Gatekeeperami w tradycyjnej i elektronicznej prawniczej komunikacji naukowej są więc przede wszystkim wydawcy czasopism, redaktorzy naczelni i kolegia wydawnicze, recenzenci. To uznane czasopisma prawnicze de facto przez dziesiątki lat określały, kto należy do mainstreamu debat o prawie, tworzyły „bariery wejścia” do świata nauki prawa ${ }^{21}$. Redakcje skutecznie mogły wykluczać możliwości podejmowania określonych tematów, kreować obszary tabu, zamykając dyskursy dla ochrony tradycyjnych, uznanych paradygmatów badań i strategii stosowania prawa, określonych wartości politycznych i prawnych. Mogły orientować się na wartości wewnętrzne albo na „modne” tematy w kraju lub na świecie, np. aby podnieść wskaźnik cytowań. Obecnie polityka - z celami innymi niż jakość badań - wkroczyła do świata polskich czasopism. „Zmiana punktacji za publikacje w czasopismach naukowych ma zapobiec utracie pewnych uprawnień przez uczelnie wyższe - wyjaśnia wiceminister" 22 .

„Skolonizowani” badacze, aby publikować, powinni pracować pod dyktando rządowego albo organizacyjnego audytora w celu uzyskania wyników, które precyzyjnie zmierzą urzędnicy ministerstwa albo inna instytucja. Kontrola wytwarzania wiedzy zmuszać ma badaczy do uległości i promuje takie wyniki, które można łatwo zmierzyć, zważyć, zrozumieć i zestandaryzować.

Jeśli ministerialna lista czasopism byłaby zgodna z listą uznaną w prawniczym naukowym środowisku, to wyznaczałaby położenie prawniczego, kulturowego centrum, poza które można byłoby wyjść, proponując inne tematy, problemy i ujęcia, ale - trzeba przyznać - nie byłyby one formalnie uznane za znaczące (w uczelniach i w instytutach badawczych), choć mogłyby być oryginalne $\mathrm{i}$ istotne poznawczo ${ }^{23}$.

Jeśli jednak lista oficjalna i środowiskowa są różne, ponieważ służą innym celom - tworzą się dodatkowe problemy. Powstawać mogą na przykład dwa nurty komunikacji, a każdy z nich będzie wpływał na katalogi tematów uznawanych za ważne, np. tworząc bariery „wejścia” - dzięki redakcjom czasopism - i skutecznie wykluczając (np. przez dobór recenzentów) możliwość podjęcia niewygodnych zagadnień. W efekcie kształtuje się skomplikowana mozaika osób należących i wykluczonych z mainstreamowych debat publicznych.

Lista ministerialna w Polsce, działajac wstecz, stwarza ponadto autorom tekstów sprzed kilku lat nieoczekiwane „prezenty” albo wymierza im „kary”. Wysoka punktacja oznacza uznanie i bezpieczeństwo pracy w miejscu pracy,

${ }^{21}$ Pomijam tu znaczenie wydawnictw, zwłaszcza wydających monografie i komentarze, artykuł dotyczy głównie krótszych tekstów, artykułów, recenzji, glos, a także opinii, raportów i ekspertyz.

${ }^{22}$ „Wiceminister Włodzimierz Bernacki o zmianach w punktacji” - Portal edukacyjny Perspektywy, 20.02.2021 <www.perspektywy.pl/portal/idex.php?option=com/> [dostęp: 20.02.2021].

${ }^{23}$ Miejsce czasopisma na liście ministerialnej ma znaczenie dla oceny parametrycznej jednostki oraz dla oceny aktywności naukowca w procesie awansu naukowego. 
a nawet być może wzmacnia legitymizację tez wyrażonych w tych czasopismach. Poważny spadek czasopisma w rankingu oznacza dla autora w nim publikującego niepewność jutra, a być może propozycję przeniesienia się na etat dydaktyczny.

Redaktorzy naczelni czasopism - licząc się z polityczną selekcją - tworzą jednak nadal jakościowe „bramki” zarówno w ramach komunikacji „otwartej”, jak i „zamkniętej” (I poziom). To redaktorzy decydują ostatecznie o profilu pisma, z wielu nadsyłanych artykułów wybieraja wraz z recenzentami do publikacji tylko niektóre z nich, decydują też o czasie ich publikacji. Kierują się wieloma przesłankami, wybieraja teksty oryginalne i istotniejsze od innych w pierwszej kolejności, ciekawsze, lepiej napisane, od osób uznawanych za autorytety. Teksty odrzucone przez recenzentów stają się naukowo „martwe”. $\mathrm{W}$ ten sposób redaktorzy i recenzenci jako gatekeeperzy nadaja w pismach rangę określonym problemom prawnym, inne uznając za nieważne. Kreuja w pewnym sensie wizję istotnych zagadnień świata prawa, mogą kreować nawet wiele wizji, jeśli naukowe środowisko jest wyraźnie podzielone.

Polityki publikacyjne (w tym decyzje o otwarciu czasopisma) są uzależnione od tradycji pism, źródeł ich finasowania, strategii uczelni, od zmiennych okoliczności społecznych i politycznych. Proces selekcji tekstów do czasopisma jest wypadkową wielu elementów, poza jakością i oryginalnością liczy się dużo innych czynników, które kształtują linie redakcyjne.

Publikacje naukowe zamieszczane w czasopismach otwartych i zamkniętych tworza fundament procesu praktycznego ugruntowywania doktryny prawniczej. Ten fakt staje się poważnym problemem, jeśli urzędowa lista czasopism jest zbyt silnie spolityzowana, zmienna i chwiejna aksjologicznie. Poza tym globalne rankingi czasopism są także mało reprezentatywne dla czasopism prawniczych spoza USA i nie sa reprezentatywne dla oceny polskich czasopism prawniczych ${ }^{24}$.

Biorąc pod uwagę fakt, że kanały uznanych prawniczych czasopism w kraju i za granicą (czyli tych, które znajdują się na krajowej ministerialnej liście czasopism, oraz tych, które znalazły się w uznanych prywatnych bazach międzynarodowych) otwierają się i zamykają w zależności od wielu okoliczności problem jest poważny ${ }^{25}$. Rankingi czasopism sa niestabilne, nie moga wobec tego stanowić przesłanek dla tworzenia wieloletnich strategii rozwoju pism ${ }^{26}$.

Przepustowość, widoczność, prestiż i tempo, w jakim ukazuje się publikacja, są trudne do wiarygodnej i stabilnej oceny, jeśli ranking jest niestabilny.

${ }^{24}$ Szeroko na ten temat: Wierczyński (2020). Tam też o błędach formalnych i materialnych polskich rankingów czasopism oraz postulaty dotyczace zmian.

${ }^{25}$ Krytycznie o liście czasopism z 9 lutego 2021 r. por. np. Uchwała nr 01/2021 PKP PAN z 15 lutego 2021 r.: „W wykazie znalazła się grupa czasopism z zakresu nauk prawnych, których punktacja została ustalona w sposób arbitralny i sprzeczny z zasadami merytorycznymi i proceduralnymi określonymi w obowiązującym w tej materii rozporządzeniu MNiSW z dnia 7.11.2018 r. [...], a więc $\mathrm{w}$ sposób niezgodny $\mathrm{z}$ prawem [...]. Władczy akt ministra nie może być działaniem arbitralnym, sprzecznym z prawem".

${ }^{26}$ Wydawcy, redaktorzy i kolegia redakcyjne w Polsce tworzą więc różne strategie, jedni orientują się na uznanie przez międzynarodowe bazy (np. Scopus, Web od Science), inni na tradycję czasopisma. 
Wobec tego autorzy w obecnej sytuacji z trudem ustalaja, które czynniki maja wziąc pod uwagę przy podejmowaniu decyzji, do jakiego czasopisma skierować artykuł27.

Jest też w Polsce dużo czasopism prawniczych typu closed access (I poziom) wydawanych przez organy prawniczych samorządów zawodowych, stowarzyszenia prawników. Wiele z nich ma wieloletni prestiż pism profesjonalnych, publikuja tam naukowcy i praktycy teksty istotne dla praktyki orzeczniczej. Wiele z tych pism zrezygnowało z walki o punkty. Ich dalszy los jest niejasny. Są dostępne w prenumeracie.

Prawnicza naukowa komunikacja nie kończy się w XXI w. na czasopismach, monografiach, konferencjach i rozpowszechnianiu w Internecie (o czym niżej), ale polega też na tworzeniu i przekazywaniu do otoczenia wyników badań o cechach wiedzy „prywatnej”, a nie publicznej, będącej partykularną własnościa jakiegoś podmiotu, który zamówił badania (z kręgu biznesu, przemysłu, polityki). Komunikowanie wyników w raportach, opiniach, ekspertyzach ma cechy closed access (II poziom). Odbiorcy wyników sa fundatorami, sponsorami, zleceniodawcami badań i chcą zachować pełną kontrolę nad wynikami. Nauki prawne zawsze oferowały wyniki o dużym potencjale wpływu społecznego i mające walor wdrożeniowy, nie wszystkie wyniki się publikuje. W tym przypadku gatekeeperami są zamawiający badania, to oni zamykają dostęp do efektów prac badawczych.

Ten rodzaj closed access w komunikacji naukowej jest nurtem o wiele mniej widocznym w literaturze i rzadko omawianym w otwartych dyskusjach naukowych. Wartości, jakim służy, są złożone i nie tak oczywiste dla przeciętnego obywatela jak bezinteresowne publikowanie wyników badań dla dobra wspólnego.

Dlaczego „prywatne wyniki badań” w komunikacji prawniczej pozostaja $\mathrm{w}$ cieniu?

Od lat osiemdziesiątych ubiegłego wieku wiele państw, w tym także Polska, nie mogąc zaspokoić z budżetów publicznych wymagań finansowych uczelni (powód: moda na publiczne, masowe, kosztowne egalitarne kształcenie), w tym wydziałów prawa, zaczęły zachęcać uniwersytety do uruchamiania alternatywnych źródeł finansowania, między innymi przez komercjalizację wyników badań. $\mathrm{Z}$ czasem ostra konkurencja, międzynarodowe rankingi i akredytacje doprowadziły do wyraźnego rozwarstwienia pracowników naukowych wydziałów prawa. Niektórzy znaleźli dla swoich badań zewnętrzne źródła finansowania, podjęli współpracę z agencjami rządowymi, przemysłem i biznesem. Zaczęli prowadzić prywatne prace badawcze, zarówno podstawowe, jak i wdrożeniowe, przynoszące duże zyski i wysokie honoraria. Inni pozostali głównie nauczycielami akademickimi publikującymi w czasopismach

${ }_{27}$ Czasopismo prawnicze mające 20 pkt otrzymuje na nowej ministerialnej liście w $2021 \mathrm{r}$. 100 pkt, inne, które miało 40 pkt, a w okresie od opublikowania ostatniej listy dostało się do bazy Scopus, nadal utrzymuje tylko 40 pkt. Międzynarodowa widoczność wyników naukowych okazuje się nie mieć znaczenia. Artykuł (10 stron) w języku polskim w piśmie awansowanym na nowej liście o trzy stopnie (z 20 pkt, poprzez 40, 70, do 100) jest o 20 pkt więcej wart niż recenzowana, szeroko dyskutowana monografia naukowa wydana w Polsce (80 pkt). 
typu open access na podstawie badań własnych i grantów publicznych. Część naukowców z wydziałów prawa zmieniła z czasem swoje relacje z otoczeniem, ośrodki swojej głównej aktywności umieściła poza uniwersytetami, w organach państwa, biznesie, w prywatnych kancelariach i firmach doradczych.

Tradycyjny model uniwersytetu Humboldta, który łączy ze sobą kształcenie i badania naukowe, nastawiony na potrzeby kadry akademickiej (faculty-centered) oraz anglosaski model wywodzacy się między innymi od Johna Henry'ego Newmana, nastawiony w większym stopniu na kształcenie i na studentów (student-centered) uzupełniać zaczął nowy model „uniwersytetu przedsiębiorczego" 28 . Ustawa $2.0 \mathrm{w}$ Polsce nie deklaruje wprost, jaki model uniwersytetu przyjmuje ${ }^{29}$. Jednak kierunek jest jednoznaczny: uczelnie maja odchodzić od modelu Humboldta w stronę uniwersytetu przedsiębiorczego.

Sheilai Slaughter i Larry Leslie przed wielu laty w pracy Academic Capitalism przeprowadzili wywiady z naukowcami z czterech krajów. Ich wniosek z wywiadów był następujący: „Sądzimy, że pracownicy naukowi jako zawodowi uczestnicy kapitalizmu akademickiego będą porzucali takie wartości, jak altruizm i służba publiczna, i zwracali się ku wartościom rynkowym"30. Mieli rację, nazwa „kapitalizm akademicki”, na określenie tych zjawisk, na stałe weszła do języka opisu sytuacji.

Open access nie przystaje oczywiście do „kapitalizmu akademickiego”. Uczelnie (w tym wydziały prawa) powinny przynosić zyski, komercjalizować wyniki badań i nawiązać silniejsze rynkowe więzi kooperacyjne z otoczeniem. Sheldon Krimsky, wybitny amerykański naukowiec, autor pracy Nauka skorumpowana?, badał te procesy i już w 2003 r. stwierdził, że „kapitalizm akademicki” jest faktem i prowadzi nie tylko do ważnych osiagnięć naukowych, ale też często do zjawisk niekorzystnych. Opisał tendencje do stronniczości nauki, powstawanie niewyraźnych granice między nauka, interesem publicznym i dążeniem do prywatnych korzyści; pomiędzy korporacjami, uniwersytetami i agencjami rządowymi zlecającymi badania naukowe. „Skoro wyższe uczelnie zmieniają swoje laboratoria w przedsiębiorstwa komercyjne, a kadrę naukową w narzędzie do realizacji celów biznesowych, coraz mniej miejsca będzie $\mathrm{w}$ nich dla nauki działajacej w interesie publicznym - z niepowetowaną strata dla społeczeństwa" ${ }^{31}$.

Ta teza Krimskiego dotyczy też sytuacji nauk prawnych w Polsce w okresie wdrażania ustawy 2.0. Wiele interesujacych naukowych badań w naukach społecznych, w tym w naukach prawnych, prowadzonych jest obecnie na zlecenie biznesu i przemysłu, a ich wyniki ujawniane sa tylko w niewielkim zakresie. Nie są rekomendowane przez zleceniodawców do bezpłatnej publikacji otwartej.

Dostosowanie polskiego środowiska prawniczego do wizji „uczelni przedsiębiorczej” nie jest łatwe, ponieważ dziś prawnik - naukowiec, który odniósł

28 Bliżej zob. Jabłońska-Bonca (2020): rozdz. IV i tam podana literatura.

${ }^{29}$ Ustawa 2.0, czyli: ustawa z 18 lipca 2018 r. - Prawo o szkolnictwie wyższym i nauce, Dz. U. poz. 1668.

30 Slaughter, Leslie (1997).

31 Krimsky (2006): 48. 
sukces, to przede wszystkim ten, który uczestniczy z sukcesem w wyścigu naukowym, co owocuje między innymi pewnymi publikacjami open access, a jednocześnie umiejętnie przekształca własną wiedzę w wiedzę „prywatną” i w honoraria pozauczelniane, jeśli potrafi być sam dla siebie project managerem. Kto powinien rozstrzygać, które informacje z dwóch światów, w których uczestniczy powinny zostać opublikowane? Na przykład, co ma zrobić, jeśli uznaje, że presja fundatora badań jest nadmierna? Czy powinien poświęcić kreatywność na rzecz oportunizmu? Kto powinien być w takiej sytuacji gatekeeperem?

Problem stronniczości w publikowaniu wyników badań i analiz w naukach prawnych w Polsce narasta w takim stopniu, że Komitet Nauk Prawnych PAN uznał za konieczne przyjęcie rekomendacji w sprawie ujawniania konfliktu interesów w prawniczych publikacjach naukowych ${ }^{32}$.

W obszarze nauki przemysłowej o darowaniu wyników społeczeństwu nie ma na ogół mowy. Poufność wyników przekazywanych zamawiającym ma tu znaczenie kluczowe, gdyż właśnie ona zapewnia standard istotności treści przekazu. W tym przypadku wyniki sa dostępne dla wybranych, a autor nie może się nimi podzielić w czasopiśmie, na swoim blogu czy w repozytorium. Naukowcy mogą wyniki - jeśli umowa z firmą to przewiduje - przekształcić w teksty popularnonaukowe, mogą też - zachowaniem zasad umowy o poufności i anonimizacji danych z firmą - umiejętnie wykorzystać uzyskaną wiedzę, ucząc studentów.

Zastosowane wyniki mogą przynosić sukcesy finansowe, gospodarcze, społeczne albo polityczne, jednak autor jest zmuszony pozostać w cieniu. W radach wydziału (teraz radach dyscyplin) zasiadają obok siebie przedstawiciele nauki akademickiej i kapitalizmu akademickiego. Na ogół niewiele wiedzą wzajemnie o swoich drogach zawodowych.

Badania aplikacyjne (wdrożeniowe), majace na celu zdobycie wiedzy oraz umiejętności, nastawione są na opracowywanie nowych zasad, struktur i procedur instytucji prawnych, zmiany istniejacych lub wprowadzanie do nich znaczących ulepszeń. Tym celom służą przede wszystkim prace dogmatycznoprawne zawierajace postulaty de lege lata oraz prace pokazujace optymalne zastosowania regulacji w praktyce. Prace rozwojowe służą wykorzystywaniu dostępnej aktualnie wiedzy i umiejętności prawniczych do planowania konkretnych zmian w prawie oraz projektowania nowych instytucji prawnych.

John Ziman, brytyjski uczony, przeanalizował, jak obok nauki akademickiej rośnie znaczenie nauki o innych własnościach, nazwał ją umownie „nauką przemysłowa” ${ }^{33}$. „Nauka przemysłowa to taka, która: tworzy wiedzę będącą czyjąś partykularną własnością [...], częściej zajmuje się rozwiązywaniem lokalnych problemów o szerszym zasięgu; podlega ścisłej kontroli; jej celem jest osiagnięcie konkretnych i praktycznych wyników; zatrudnia raczej

32 Rekomendacja z 3 lutego 2021 r. KNP PAN, <http://www.knp.pan.pl/> [dostęp: 20.02.2021]; cyt: „konflikt interesów może mieć miejsce w przypadku występowania związku autorek lub autorów z instytucja, przedsiębiorstwem lub urzędem publicznym [...], które są bezpośrednio zainteresowane lub czerpią korzyści z przyjęcia określonej interpretacji prawa”.

33 Bieliński (2016). 
ekspertów od rozwiązywania określonych problemów niż ludzi prowadzących niezależne i niezdeterminowane niczym badania" ${ }^{34}$. Własności wiedzy tego typu - bez względu, czy jest wytwarzana dla przemysłu czy dla władzy publicznej - zostały wskazane trafnie.

Wyraźne różnice między nauką akademicką a „przemysłową” (i ekspercką dla organów władzy) polegają na odmiennym poziomie autonomii badań i dostępności wyników. W nauce akademickiej kontrola nad naukowcem uważana jest za ograniczenie jego autonomii poznawczej, grozi zachwianiem bezstronności wyników. Wyniki powinny być przekazane społeczeństwu, w „otwartym dostępie”, należy się nimi dzielić. W „nauce przemysłowej” (i eksperckiej dla organów władzy) - kontrola nad informacją i poufność wyników ma znaczenie kluczowe dla zleceniodawcy. Efekty badań uzyskuje się dla rozwiązania konkretnych zagadnień i często nie ujawnia się ich w całości. Rodzi to problemy w przypadku badań dla organów władzy z uwagi na przepisy o dostępie do informacji publicznej ${ }^{35}$. Powstają też dylematy związane z ujawnianiem konfliktów interesów ${ }^{36}$.

W końcu warto też zauważyć, że obok obszaru wiedzy „zamkniętej” rośnie obszar jawnej, demokratycznej nauki, ponieważ uznaje się, że mimo tendencji do komercjalizacji wyników badań przekazywanie wiedzy społeczeństwu jest także ważnym obowiązkiem naukowców ${ }^{37}$. Nie wszyscy naukowcy uważaja, że do ich obowiązków należy zwracanie się wprost do opinii publicznej, wielu twierdzi, że tym samym przekraczają granice profesji. Ale wszyscy mają świadomość, że oczekuje się od nich w XXI w. kontaktów z otoczeniem.

Wprawdzie Internet spowodował, że każdy naukowiec może być autonomicznym nadawcą przekazu, takich możliwości nie było w erze tradycyjnych masowych środków przekazu, nie oznacza to jednak, że każdy umie komunikować się z osobami niebędącymi naukowcami. Większość naukowców nie przechodzi formalnego szkolenia w zakresie publicznego przekazywania wiedzy naukowej ${ }^{38}$.

Ponadto media cyfrowe $\mathrm{z}$ jednej strony umożliwiły otwarty i wolny dostęp do wiedzy prawniczej, a z drugiej - mają także swoich zupełnie nowych gatekeeperów. Selekcjonerami są sami odbiorcy komunikatów oraz komercyjne wyszukiwarki internetowe ${ }^{39}$. Nie wiadomo przecież, dlaczego te, a nie inne informacje pokazują się jako pierwsze. System źródeł informacji w Internecie jest nieprzejrzysty. Władza nad informacja znajduje się $\mathrm{w}$ istocie $\mathrm{w}$ rękach globalnych firm - „prywatnych mocarstw” ${ }^{40}$. „Wiedza to dobro publiczne, które

${ }^{34}$ Ziman (2000): 33.

35 Ustawa z 6 września 2001 r. o dostępie do informacji publicznej, Dz. U. 2001, Nr 112, poz. 1198.

36 Zob. przyp. 32.

${ }^{37} \mathrm{Na}$ styku powstają poważne etyczne problemy konfliktu interesów, to zagadnienia praktyki i polityki w badaniach finansowanych ze źródeł zewnętrznych.

38 Oczywiście wyjątek stanowi dla prawników dialog zawodowy: większość naukowców ma jednocześnie aplikacje, wielu praktykuje w zawodach prawniczych i prawie każdy może uczestniczyć w profesjonalnym dogmatycznoprawnym dyskursie zawodowym.

39 Szpunar (2013).

40 Określnie Asha (2018). 
jest dostarczane przez prywatne mocarstwa" - zauważa Timothy Garton Ash, mając na myśli na przykład Google (obecnie: Alphabet) ${ }^{41}$. Wyszukiwarki sa pozornie neutralne, ale faktycznie na wiele sposobów decyduja jakie wyniki badań (np. prawniczych) będą publicznie i darmowo (albo odpłatnie) rozpowszechniane. To zjawisko zwane jest tzw. gatekeepingiem technologicznym.

Wyszukiwarka „staje się kolejną brama, odźwiernym, determinującym, które informacje i w jakiej formie do nas trafiaja" ${ }^{42}$. Wyszukując teksty prawne, wiemy, że twórcy wyszukiwarki przyjęli określoną hierarchię wartości, jest ona niejawna, ale jedno jest pewne: to hierarchia komercyjna ${ }^{43}$.

Dotarcie do adresatów ogłaszanych wyników naukowych nie zależy od nadawcy, ale też od odbiorcy, który swobodnie serfuje w cyberprzestrzeni. To odbiorca wraz z wyszukiwarka jest teraz gatekeeperem!

Skoro każda informacja o prawie może być natychmiast wygooglowana, to na jakiej podstawie specjalny autorytet ma mieć na przykład profesor prawa, autor artykułu w czasopiśmie naukowym? Każdy może przecież „zdobyć” wiedzę wprost z Internetu bez pośrednika, jakim jest profesjonalista - tak sądzą często nieprawnicy. Zainteresowany informacją prawną nieprawnik nie ma metodologicznego przygotowania, nie zna zasad etyki pracy naukowej, nie dysponuje wobec tego kryteriami, które pozwoliłyby mu odróżniać wiedzę użyteczną od wiedzy godnej zaufania czy informacje prawdziwe od fałszywych. Dla nauk prawnych taki mit wiedzy prawniczej jako taniego i dla każdego dostępnego „towaru”, który bardzo łatwo można uzyskać, ma daleko idące konsekwencje społeczne i polityczne, o wiele głębsze niż w naukach przyrodniczych czy technicznych. Zaciera między innymi specyficzną rolę, jaką pełni i pełnić powinna ustalona doktryna prawnicza. Nie jest to przecież wyłącznie rola neutralnego badacza zjawisk prawnych. Wiedza (a może raczej zbiór informacji), która „zdobywa” się w sieci, a nie z tradycyjnego czasopisma czy podręcznika, jest hipertekstualna, ma strukturę rozgałęziona, składającą się z wielu fragmentów łączących się ze sobą poprzez liczne odsyłacze. Wybór i sposób wiązania fragmentów zależy od decyzji odbiorcy komunikatu. To on jest teraz głównym selekcjonerem ${ }^{44}$. Czuje zazwyczaj, że jest autonomicznym, upodmiotowionym autorytetem.

Prawnicza komunikacja naukowa została w ostatnim ćwierćwieczu wzbogacona także o różne nowe formy otwartej, autorskiej promocji samych naukowców i ich dorobku oraz szeroko dotarła do różnych kategorii nowych podmiotów. Otworzyła się też globalnie na kontakty naukowe, które można teraz szybko nawiązywać. Rozwój otwartej prawniczej komunikacji w Inter-

41 Ash (2018): 269.

42 Ash (2018): 61.

${ }^{43}$ Warto zauważyć także, że w pozornie „bezbramkowym” świecie Internetu wolni uczestnicy komunikacji mogą być ignorantami prawnymi, wprowadzającymi nieświadomie albo świadomie czytelników w błąd. Są to nie tylko działajacy pro publico bono popularyzatorzy wiedzy prawniczej, ale także mitomani, niebezpieczni dyletanci oraz profesjonalni dezinformatorzy. Pojawiaja się w komunikacji prawniczej niezależnie od tego, czy zostali zaproszeni do udziału w konkretnym dyskursie naukowym czy nie. Postępują też prace nad sztuczną inteligencją. Na świecie jest coraz więcej udanych prób pisania tekstów z przeglądami informacji naukowych przez boty.

44 Szeroko na ten temat: Jabłońska-Bonca (2018). 
necie jest nie do przecenienia w demokratycznych społeczeństwach, prawnicy powinni przedstawiać społeczeństwu wyniki badań prowadzonych za środki publiczne, poddawać je społecznej ocenie, treści zawarte w prezentowanych tekstach powinny pomagać w podejmowaniu decyzji przez obywateli.

Trzeba przyznać, że w Polsce ustawa 2.0 nie doceniła roli naukowca jako popularyzatora nauki. Nie ma w polityce naukowej państwa ani w ustawie 2.0 przepisów tworzących źródła motywacji do podejmowania przez naukowców aktywności tego typu. W praktyce decydują więc indywidualne chęci tych pracowników, którzy rozumieją wagę popularyzacji, autopromocji i szukaja kontaktów z otoczeniem. Niekiedy jest to także wymóg grantodawcy, a popularyzacja jest efektem realizacji zobowiązań wobec instytucji finansującej badania.

Działają liczne naukowe serwisy społecznościowe (academic social networks), np. ResearchGate czy Academia.edu, ale prawnicy w Polsce nie korzystają z nich powszechnie ${ }^{45}$. Głównym celem tych serwisów jest budowanie sieci komunikacyjnych wśród naukowców, udostępnianie danych badawczych i informacji na temat prowadzonych badań, grantów oraz inicjowanych projektów badań.

Są też inne profesjonalne portale, które mają narzędzia nadające się do wykorzystania w komunikacji na temat nauki, choć na razie nie sa także zbyt aktywnie użytkowane przez prawników ${ }^{46}$. Naukowcy zauważyli na przykład walory serwisu LinkedIn, który początkowo był uznawany za „wirtualne CV”. Obecnie to serwis głównie biznesowy, ale dający też duże możliwości marketingu naukowego ${ }^{47}$. Portal wprowadził opcję wewnętrznego bloga. Skuteczność popularyzacji wiedzy prawniczej oraz jej transferu do praktyki mogłaby być z jego pomoca wysoka ${ }^{48}$. Starszą formą otwartej internetowej komunikacji prawników z otoczeniem są prawnicze blogi o treściach naukowych. Naukowcy umieszczają na nich datowane wpisy, wyświetlane kolejno, zaczynajac od najnowszego ${ }^{49}$. Blogi umożliwiają szybkie umieszczenie postów, co daje im przewagę nad czasopismami naukowymi. Są widoczne i bezpłatne. To otwarta komunikacja selekcjonowana przez wpływ wyszukiwarek.

Posty nie są wypowiedziami naukowymi recenzowanymi, nie sa selekcjonowane, nie są więc uznawane za teksty naukowe. To jedynie forma marketingu osobistego oraz droga nawiązywania kontaktów naukowych. Anonimowość osób dyskutujących z blogerem czyni tę formę kontaktów dyskusyjną.

Komunikacja za pomocą serwisu społecznościowego, jakim jest Twitter, pozwala na nieprzekraczające 140 znaków wiadomości tekstowe wyświetlane na stronie użytkownika oraz dostarczane pozostałym użytkownikom, którzy obserwują dany profil. Chodzi tu także o autopromocję oraz o promowanie włas-

${ }^{45}$ To moja hipoteza, sprawdzona wyrywkowo.

${ }^{46}$ To także hipoteza, sprawdzona wyrywkowo.

${ }^{47}$ G. Furgał, <http://www.gfpr.pl> [dostęp: 20.02.2021].

${ }^{48} \mathrm{Na}$ razie jest wykorzystywany głównie przez przedstawicieli biznesu, którzy systematycznie publikują wyniki badań i raporty, tworząc w ten sposób portfolio własne lub reprezentowanej firmy, pozyskując nowe kontakty biznesowe oraz partnerów do przyszłych badań.

$49<$ www.lawprofessors.com/>. Blogi sa popularne w USA, w Polsce nie bardzo. W USA np. blog R.A. Posnera i G. Beckera, <www.becker-posner-blog.com/> [dostęp: 28.02.2021]. 
nych albo cudzych tez, wskazywanie miejsc ogłoszenia artykułów czy miejsc i dat wygłaszania referatów, co może mieć wpływ na cytowalność.

Krajobraz komunikacyjny uzupełniaja w coraz szerszym zakresie prawnicy - eksperci zatrudniani w działach PR i marketingu naukowym w agencjach rządowych, biznesie, organizacjach pozarządowych i innych podmiotach. Ich celem jest zapewnienie zrozumiałych dla społeczeństwa i naukowo dokładnych materiałów komunikacyjnych. Przygotowuja popularnonaukowe treści prawnicze na strony internetowe instytucji. Tworza tradycyjne i elektroniczne broszury i popularnonaukowe raporty z badań, które są dla ich firm wykonywane. W ten sposób udostępniają bezpłatnie wiedzę prawniczą w profesjonalnej formie i nieanonimowo.

Największe przeobrażenia krajobrazu otwartej prawniczej komunikacji naukowców dokonują się obecnie za pośrednictwem repozytoriów naukowych zapewniajacych proste metody ogłaszania, przechowywania, wyszukiwania i udostępniania publikacji. Czy repozytoria maja gatekeeperów? Uznaje się, że stworzenie sieci repozytoriów przekłada się na wzrost liczby cytowań i poszerza możliwości nawiązywania kontaktów naukowych. Ponadto przyczynia się do lepszego wykorzystania wyników badań w praktyce. Prawnicy także z tego medium nie korzystają masowo, chyba że instytucja zatrudniająca naukowca ma własne repozytorium i sama tam umieszcza prace. „Repozytorium to narzędzie informatyczne, służące do deponowania, przechowywania i udostępniania w formie elektronicznej dorobku naukowego (publikacji i wyników badań) instytucji naukowych (repozytorium instytucjonalne) lub z określonych dziedzin nauki (repozytorium dziedzinowe) ${ }^{50}$. Repozytoria tworzą różne podmioty, publiczne i prywatne (np. uniwersytety, instytuty naukowe). Wydawcami sa na ogół biblioteki. W repozytoriach umieszczane sa przede wszystkim artykuły naukowe, które otrzymały dofinansowanie publiczne, a więc takie, które powinny zapewnić otwarty (darmowy) dostęp gratis (Gratis Open Access) albo otwarty (wolny) dostęp libre (Libre Open Access) ${ }^{51}$.

Niektóre repozytoria zawierają wyłącznie recenzowane artykuły z czasopism, inne także prace doktorskie, materiały dydaktyczne, pierwotne dane, raporty, sprawozdania, preprinty i postprinty. Selekcja materiałów jest więc także w tych miejscach. Regulaminy repozytoriów ustalane przez zakładajace je instytucje określają zakres gromadzonych treści. W polskich repozytoriach instytucjonalnych umieszczane są przede wszystkim utwory, czyli materiały podlegajace ochronie wynikajacej z norm ustawy z 4 lutego 1994 r. o prawie autorskim i prawach pokrewnych, a ponadto materiały niechronione, czyli teksty i inne formy wyrazu, które nie spełniają kryteriów „utworu” (np. różne spisy i wykazy $)^{52}$. Można też w nich umieszczać utwory znajdujące się w do-

50 Bujko (2018).

51 Siewicz (2012: 12): „W otwartym dostępie gratis chodzi o udostępnienie publikacji naukowych [...] w publicznym Internecie, bez blokad technicznych i opłat. Natomiast otwarty dostęp libre zachodzi, jeżeli poza udostępnieniem publikacji w powyższy sposób zostanie do niej udzielona licencja na nieograniczone, nieodpłatne i niewyłączne korzystanie z oryginałów oraz z ich ewentualnych opracowań (wolna licencja)".

${ }_{52}$ Dz. U. 2017, poz. 880. 
menie publicznej, czyli te, do których wygasła ochrona wynikajacca z prawa autorskiego, oraz rozprawy doktorskie, prace magisterskie, licencjackie i dyplomowe powstałe w jednostkach prowadzacych repozytoria ${ }^{53}$. Moment deponowania materiału w repozytorium jest opatrzony data, godziną i miejscem. Pozwala to ustalić pierwszeństwo ustalenia treści utworu.

W Polsce w repozytoriach należy umieszczać teksty z czasopism otrzymujaccych dofinansowanie publiczne, ponieważ powinny one zapewniać otwarty dostęp gratis lub libre. Dyskusyjna jest sprawa publikacji w czasopismach, które nie otrzymują dofinansowania, a ich wydawcy nakładaja embargo.

Repozytoria polskie zawierają na razie niewiele prawniczych publikacji naukowych ${ }^{54}$. Autorzy, nie będąc zobowiązanymi do ich archiwizacji i upowszechniania, na ogół nie robią tego. Uczelnie i instytuty naukowe nie przedstawiają swoim pracownikom korzyści, jakie z tego płyną. Niektórzy z pytanych prawników w ogóle nie wiedzieli o takiej możliwości.

Początki tworzenia sieci repozytoriów w świecie wzbudziły bardzo poważne dyskusje w środowisku wydawców naukowych. Niepokoje te przeniosły się także do Polski. Wydawcy uważali, że model otwartego publikowania zagraża ich komercyjnym modelom wydawniczym ${ }^{55}$.

Krytycy repozytoriów podnoszą, że nie można w nich często archiwizować materiałów, które nie zostały ujęte w artykule z powodu limitu objętości tekstu. Ponadto repozytoriom społecznym często brakuje profesjonalnej redakcji czuwającej nad selekcją jakościową tekstów. W wielu repozytoriach każdy użytkownik może zamieścić dowolny artykuł. Nie ma więc w ogóle gatekeeperów. Repozytoria oferują możliwość dokonywania adnotacji, integracji i eksportowania danych, publikowania danych w uzgodnionych formatach oraz możliwość monitorowania zainteresowania danym tekstem za pomocą statystyk.

Powstawanie repozytoriów spowodowało zamieszanie: e-artykuły są teraz często wielokrotnie archiwizowane, nie ma jasności co do sposobów cytowania. Po pierwsze, e-czasopisma w systemie open access pełnia de facto funkcje repozytoriów (archiwizują własne edycje); po drugie, artykuły są umieszczane w repozytoriach uczelni czy innych podmiotów; po trzecie, czasem trafiają do innych repozytoriów (np. społecznych); po czwarte, są umieszczone przez autorów na prywatnych internetowych stronach; po piąte, bywają załaczone do bloga autora; po szóste, są załącznikami do portali (np. portalu LinkedIn ${ }^{56}$ ).

${ }^{53}$ Repozytoria jako serwisy internetowe podlegają ustawie z 18 lipca 2002 r. o świadczeniu usług drogą elektroniczną (Dz. U. 2002, Nr 144, poz. 1204), która nakłada na usługodawcę (w tym przypadku twórców repozytorium) liczne obowiązki.

54 To hipoteza, sprawdzałam wybiórczo.

55 Bednarek-Michalska (2017): 17.

${ }^{56}$ Komisja Europejska, wspiera open access, instytucjonalne zarządzanie wynikami badań i publikacjami za pośrednictwem repozytoriów, współpracę między sieciami repozytoriów, na przykład w ramach projektu OpenAIRE. Finansuje też europejską chmurę dla otwartej nauki, federację infrastruktur danych w Europie i poza nią. Por. też Konkluzję Rady Unii Europejskiej z 27 maja 2016 r. - Przejście na system otwartej nauki, określająca cel, jakim jest uzyskanie do 2020 r. obowiązku publikowania wyników badań fnansowanych ze środków publicznych w modelu otwartym (Konkluzja Rady Unii Europejskiej z 27 maja 2016). 
Jeśli autor zamieszcza w repozytoriach nie tylko tekst opublikowany w czasopiśmie, lecz także preprinty i postprinty, sytuacja się komplikuje $\mathrm{e}^{57}$.

Pod wpływem nowych mediów autor tekstu, uznając go we własnym przekonaniu za tekst naukowy, uzyskał wiele nowych dróg komunikacji. Może na ogół bez ograniczeń, poza obszarem „nauki prywatnej”, sam decydować o umieszczeniu swoich ustaleń w wielu miejscach w przestrzeni publicznej. Może rozpowszechnić tekst w Internecie. Wyszukiwanie tekstu to zadanie odbiorcy, ale nie jest ono autonomiczne, wyszukiwarka to także zewnętrzny selekcjoner. Pozostaje też problem formalnoprawnego braku uznania tak ujawnionego tekstu za tekst naukowy i sposobów wykorzystania go w prowadzonych badaniach.

Gatekeeperzy w czasopismach naukowych nie zniknęli, władza autorów na tekstami jest z nimi nadal dzielona, Internet nie zmienił zasad w tym zakresie, choć wzmocnił pozycję odbiorcy tekstu. Teksty prezentowane w repozytoriach czy na innych prywatnych stronach nie są uznawane za artykuły naukowe, jeśli nie sa recenzowane i publikowane jednocześnie w czasopismach naukowych. Najważniejszym gatekeeperem w Polsce pozostaje polityka naukowa państwa. Internet nie uwolnił komunikacji naukowej od urzędowej instytucjonalizacji.

Warto byłoby zbadać bliżej te zagadnienia, ich wpływ na kreowanie rzeczywistości prawnej w XXI w., na wartościowane jakości badań i na tworzenie obszarów tabu w nauce.

Ash, T.G. (2018). Wolne słowo. Dziesięć zasad dla połączonego świata. Tłum. M. Godyń, F. Godyń. Kraków.

Bednarek-Michalska, B. (2017), Otwarta nauka w Polsce - rys historyczny, [w:] E. Kulczycki (red.), Komunikacja naukowa w humanistyce. Poznań: 113-128. <https://repozytorium.amu. edu.pl/bitstream/10593/17593/1/Bozena_Bednarek_Michalska.pdf> [dostęp: 20.02.2021].

Bieliński, J. (2016). Etos nauki w Polsce. Nauka akademicka, postakademicka, czy przemysłowa? doi:10.13140/RG.2.2.33991.09129.

Bujko, A. (2018). Polityka otwartości i repozytoria naukowe. Zarządzanie Bilioteką 1. <https:// czasopisma.bg.ug.edu.pl/index.php/ZB/article/view/3550> [dostęp: 20.02.2021].

Conte, S. (b.r.) Making the choice: Open Access vs. traditional journals. $<$ https://www.aje.com/arc/ making-the-choice-open-access-vs-traditional-journals/> [dostęp: 28.02.2021]

Gannon, F. (2004). Open access and closed option. EMBO Rep 5(10): 921. doi:10.1038/sj.embor.7400270.

Jabłońska-Bonca, J. (2018). Trzeba uczyć inaczej. Kilka uwag o homo zappiens i miękkich umiejętnościach komunikacyjnych prawników. Krytyka Prawa 10(2: Niezależne studia nad prawem): 373-374. doi:10.7206/kp.2080-1084.210.

Jabłońska-Bonca, J. (2020). O szkolnictwie wyższym i kształceniu prawników. Warszawa.

Karcz, J. (2016). Gry organizacyjne i polityczna perspektywa analiz organizacji, [w:] K. Klincewicz (red.), Zarządzanie, organizacje i organizowanie - przegląd perspektyw teoretycznych. Warszawa: 173-184.

Krimsky, S. (2006). Nauka skorumpowana? Tłum. B. Biały. Warszawa.

Kulczycki, E. (2013). Otwarte czasopisma. Zakładanie czasopism naukowych oraz transformacja czasopism zamkniętych. Torun.

Kulczycki, E. (red.) (2017). Komunikacja naukowa w humanistyce. Poznań.

${ }^{57}$ Oba typy dokumentów samoarchiwizuje się w repozytoriach naukowych, jest to proces realizacji tzw. zielonej drogi open access. 
Łojko, E. (red.) (2013). Prawnicy i dziennikarze - współpraca, rywalizacja, manipulacja. Warszawa.

McCombs, M. (2008). Ustanawianie agendy. Media masowe i opinia publiczna. Kraków.

Mrozowska, S. (2017). Od publicznego rozumienia nauki do komunikacji naukowej. Uwarunkowania rozwoju komunikacji naukowej w Polsce. Cywilizcja i Nauka 15. <https://czasopisma. bg.ug.edu.pl/index.php/cywilizacja/article/view/3047> [dostęp: 20.02.2021].

Schmitz, J. (2017). Open access vs. closed access: what's the difference between publishing in open access journals and in non-open access journals? <https://www.publisso.de/en/advice/ publishing-advice-faqs/open-access-vs-closed-access> [dostęp: 20.02.2021].

Shoemaker, P., Vos, T. (2009). Gatekeeping Theory. New York.

Siewicz, K. (2012). Otwarty dostęp do publikacji naukowych. Kwestie prawne. Warszawa.

Slaughter, S., Leslie, L. (1997). Academic Capitalism: Politics and Enterpreneural Univesity. Baltimore.

Szpunar, M. (2013). Wokół koncepcji gatekeepingu. Od gatekeepingu tradycyjnego do technologicznego, [w:] I.S. Fiut (red.), Idee i myśliciele. Kraków: 55-65.

White, D. (1950). The gate-keeper: a case-study in the selection of news. Journalism Quarterly 27: 383-390.

Wiengart, P., Guenther, L. (2016). Science communication and the issue of trust. Journal of Science Comunication 15(6). doi:10.22323/2.15050301

Wierczyński, G. (2020). Problemy oceny parametrycznej polskich czasopism naukowych z dziedziny nauk prawnych. Państwo i Prawo 75(9): 3-22.

Ziman, J. (2000). Real Sience. Cambridge.

\section{ON THE ISSUE OF GATEKEEPERS IN JURISTIC SCHOLARLY COMMUNICATION}

\section{Sum mary}

The article addresses selected problems associated with the subjects who have a significant influence on the selection of legal scientific research results that are disclosed, published, delivered to addressees, and which are sometimes treated as confidential and classified. These are tasks that can be considered as those of a special selector, or gatekeeper, in juristic scientific communication. Juristic scientific communication is understood in this text as communication between legal scientists, and as communication that is transformed into legal practice. It also encompasses the communication of commissioned research results by scientists to other external stakeholders, and the communication between scientists and the public. The questions posed in this text are as follows: are the paths of legal scholarly communication currently changing and, if so, how? Who has an important or decisive influence on the filtering of legal research results that enter public legal discourse, and who may close certain 'gates' and why - given that these factors prevent scholars, practitioners and the public from accessing certain content? Does digital culture have an impact on the phenomena of gates? Does the fact that open scholarly communication (open access) is developing dynamically have any influence on who is a gatekeeper?

Keywords: juristic scientific communication; law journals; gatekeeper; open access 
